\title{
Arbeid med verdier i skolen På jakt etter verdier i minnematerialet etter 22. juli 2011
}

\author{
Av Sidsel Lied (f. 1948), Ph.D, prof. emerita i religionsdidaktikk ved Høgskolen i Hedmark. \\ E-post: sidsel.lied@hihm.noog \\ TORLEIF KvesET (f. 1989), læererstudent ved Høgskolen i Hedmark. E-post: torleifkveset@hotmail.com \\ Adresse: Høgskolen i Hedmark, postboks 40o, 2418 Elverum.
}

\begin{abstract}
Barn var opptatt av verdier i tiden etter terrorangrepene 22. juli 2011. ${ }^{1}$ Det går fram av tekster og tegninger som barn og unge la på spontane minnesteder bl.a. $i$ Osloområdet. Denne artikkelen viser at mange av disse ytringene er gode utgangspunkt for arbeid i skolen når verdier som formålsparagrafen framhever skal vœre sentrale i norsk skole, står på timeplanen. Artikkelen argumenterer for hvorfor disse ytringene er et godt lceremiddel $i$ et slikt arbeid, og demonstrerer hvordan minnematerialet kan brukes på mellomtrinnet og i ungdomsskolen, både når verdier som $i$ ytringene løftes fram som verdier verdt å kjempe for står $i$ fokus, og når en skal undervise om grunnleggende verdier som settes under press.
\end{abstract}

I barns og unges tekster og tegninger fra minnematerialet etter 22. juli-terroren $\mathrm{i}$ 2011, løftes verdier som kjærlighet og samhold, liv og menneskeverd, fram som verdier det er verd å slå ring om og kjempe for. Men det går også fram av noen av disse ytringene at grunnleggende verdier som liv og respekt for menneskeverdet var truet eller under press i dagene etter terrorangrepene. Flere av de verdiene som løftes fram som viktige i minnematerialet, hører til blant verdiene som norsk skoles formålsparagraf presenterer som grunnleggende (se Lied og Stub $\emptyset$ (2016) - artikkelen «Verdier i formålsparagraf og minnematerialet etter 22. juli 2011» i dette nummeret av Prismet).

I denne artikkelen argumenterer vi først for hvorfor barns og unges tekster og tegninger fra minnematerialet kan være et

1 Den 22. juli 2011 bombet Anders B. Breivik bygninger i regjeringskvartalet i Oslo. Åtte mennesker ble drept og mange skadd. Noen timer senere samme dag skjøt og drepte Breivik 69 ungdommer som deltok på Arbeiderpartiets sommerleir på Utøya. Enda flere ble såret. Dagene etter terrorangrepene var preget av rosetog og minnesamlinger på gater og torg over hele landet. På spontane minnesteder ble det tent lys og lagt ned roser og hilsener fra barn, ungdommer og voksne i form av tekster og tegninger som inneholdt trøsteord, verdiutsagn, bønner og uttrykk for sorg, sjokk og sinne (Aagedal, Botvar, \& Høeg, 2013; Lied \& Lödén, 2014; Lied \& Undseth Bakke, 2013; Stormark, 2011). Riksarkivet i Norge samlet inn, tok vare på og digitaliserte 25000 dokumenter fra de spontane minnestedene i Oslo og Utvika (Norli \& Gausdal, 2013). Slik ble de gjort tilgjengelige for forskning. Det er tekster og tegninger fra dette digitaliserte materialet vi i denne artikkelen kaller «minnematerialet». Inneværende nummer av Prismet inneholder tre artikler som alle handler om minnematerialet. Lieds og Stubøs artikkel «Verdier i formålsparagraf og minnematerialet etter 22. juli» undersøker hvilke verdier som kommer til uttrykk i de aktuelle tekstene og tegningene, og viser at dette er verdier som i stor grad faller sammen med verdier i skolens formålsparagraf. Deres artikkel danner bakgrunn for både denne artikkelen og artikkelen «Dialoger om verdier i grunnskolens formålsparagraf - med minnematerialet fra 22. juli som læremiddel» av Stubø og Markeng, som gir eksempler på hvordan minnematerialet kan være et egnet læremiddel når læreren skal arbeide med verdier som formålsparagrafen framhever skal være sentrale i norsk skole. Siden de tre artiklene henger sammen, vil det forekomme noen gjentakelser, samtidig som hver artikkel løfter fram forskjellige hovedperspektiver. Artiklene kan leses både som en helhet og hver for seg. Lieds arbeid med minnematerialet er en del av prosjektet Kritiske hendelser, Verdier og Nasjonal identitet (KVN-prosjektet) som studerer det digitaliserte minnematerialet. De andre forskerne som deltar i prosjektet, er professor Geir Skeie, UiS og Stockholms universitet, professor Kerstin von Brömssen, Högskolan Väst, og dosent Hans Lödén, Karlstads universitet. PhD-stipendiat Sidsel Undseth Bakke, UiS, er også tilknyttet prosjektet. 
nyttig læremiddel på grunnskolens mellom- og ungdomstrinn når en skal arbeide med de verdier som skolens formålsparagraf løfter fram som grunnleggende. Så presenterer vi kort et «arbeidsredskap» som det kan være fruktbart for elevene å bruke i dette arbeidet, nemlig Gunther Kress' og Theo van Leeuwens grammatikk for vestlig visuell design. ${ }^{2}$ Deretter bruker vi dette redskapet fritt og selektivt i analysen av utvalgte ytringer fra minnematerialet og viser hvordan det kan brukes $\mathrm{i}$ undervisningen på henholdsvis mellomog ungdomstrinnet. Vi analyserer først en ytring ved hjelp av dette redskapet, med henblikk på hvilke verdier ytringen løfter fram. Underveis $\mathrm{i}$ analysen presenterer vi spørsmål og arbeidsoppgaver som læreren kan bruke når han/hun arbeider med sine elever med den enkelte ytringen. Disse spørsmålene er ment som forslag og inspirasjon. Hver enkelt lærer må selvsagt selv fritt benytte disse eller finne alternative spørsmål som er gode for sin elevgruppe å arbeide med. Til slutt presenterer vi en erfaring med minnematerialet som læremiddel som lærerstudent Kveset gjorde i en klasse på 9. trinn i en av sine praksisperioder.

\section{HVORFOR BRUKE MINNEMATERIALET SOM LEREMIDDEL I SKOLEN?}

En av grunnene til at vi setter barns og unges tekster og tegninger fra minnematerialet i fokus som læremiddel, er at minnematerialet etter 22. juli løfter fram verdier som grunnskolens formålsparagraf kaller grunnleggende. Dette samsvaret er i seg selv interessant. Men hovedgrunnen er likevel at minnematerialet presenterer disse verdiene i et språk som barn og unge er vant med, fordi de er skrevet og tegnet av barn og unge som har bakgrunn i og er en del av det samme fellesskapet eller systemet, nemlig norsk skole. Barns og unges tekster og tegninger etter 22. juli ble riktignok ikke til i barnehagen eller på skolen, for 22. juli er en dato som hører til innenfor sommerferien. Minnematerialet ble altså til innenfor andre sosiale fellesskap enn skolen. Men norske barn og unge deltar i skolens undervisning og sosiale liv store deler av året, og de deltar her $\mathrm{i}$ framforhandling av kunnskaper og rutiner hele skoleåret gjennom. Disse forhandlingene foregår innenfor rammen av skolens nasjonale læreplaner og de mål, kunnskaper og ferdigheter den presenterer. Barn og unge i Norge har følgelig mange felles referanserammer når det gjelder kunnskaper og ferdigheter, bl.a. når det gjelder hvordan en uttrykker seg skriftlig og muntlig. Når de f.eks. skriver og tegner, griper de til det repertoaret de har lært både i samfunnet rundt seg og på skolen for å kommunisere skriftlig. Dette er de vant til å bruke når de skal gjøre seg forstått gjennom skrift og bilde, og for å få fram det de ønsker å uttrykke. De anvender sjangre og uttrykksformer som de er vant med fra skolen, men lar også sin egen stemme prege disse kommunikasjonsformene (Dewilde \& Igland,

2 Se Lied og Stubø (2016) - foregående artikkel - for en noe mer fyldig presentasjon og anvendelse av denne grammatikken. 
2015; Lied, 2004). ${ }^{3}$ Det at minnematerialets tekster og tegninger fra barn og unge har mange felles trekk, kan derfor være uttrykk for at i arbeidet med à gi uttrykk for tanker og følelser, har barn og unge gjort bruk av et felles repertoar for kommunikasjon. De dro veksler på både form- og innholdsmessige ressurser som inngikk i deres felles referanseramme, da de ytret seg og la tekster og tegninger på spontane minnesteder som Domkirkeplassen og Utvika i dagene etter terroren.

Det er imidlertid ikke bare rutiner for kommunikasjon som hører til norske elevers felles referanseramme. Norsk skole er ikke verdinøytral, noe både læreplanverk og formålsparagraf gir uttrykk for (Kunnskapsdepartementet, 2009 \$1-1; Kunnskapsdepartementet \& Utdanningsdirektoratet, 2006). Skolen skal, ifølge disse dokumentene, bidra til å formidle verdier til den oppvoksende slekt. I skolens undervisning møter elevene verdier, og de kan så være enige eller uenige med disse, de kan bygge videre på dem, de kan komme med innvendinger og motargumenter mot dem, eller de kan oppleve dem som allerede akseptert og kjent. Spor av slike møter med verdier ser vi i barns og unges tekster og tegninger fra minnematerialet etter 22. juli. Barn og unge har reagert på handlingene med både engasjement og empati, fortvilelse og sinne (Lied og Stubø 2016). Mange skrev og tegnet det de tenkte og følte, og la ytringene sine på de spontane minnestedene som oppsto rundt om i landet. Ytringene inneholder kjærlighets-, samholds- og omsorgsutsagn, men også fortvilelse, sinne og hat. Slik nestekjærlighet og solidaritet kom til uttrykk, gjorde også hat, rasisme og fremmedfrykt det (jfr. f.eks. Stormark, 2012). Det er lett å få inntrykk av at et samlet Norge gikk i rosetog eller fakkeltog og la ned roser etter 22. juli. Disse uttrykkene var noe mediene la stor vekt på og statsministeren snakket varmt om, samtidig som han fremmet «... mer demokrati ... mer humanitet. Men aldri naivitet» (Stoltenberg, 2011). Står vi likevel i fare for å være litt naive når vi ser tilbake på tiden etter 22. juli og klapper oss selv på skulderen for en godt gjennomført jobb der vi møtte ondskap med kjærlighet? Faren for dette er til stede, men barns og unges ytringer framhever det positive som skjedde i denne tiden, uten å la de negative aspektene bli borte. De kan derfor gi oss innsikt i hvordan vi, uten å bagatellisere hvordan Norge sto sammen i tiden etter 22. juli eller alt det gode som kom ut av det vonde, også kan ta tak i det som setter sentrale verdier under press (se også Lippestad, 2013; Stormark, 2012). De kan, med andre ord, hjelpe oss å minnes terrorhendelsen - som en del av vårt kollektive minne (Lied \& Undseth Bakke, 2013).

3 Aktivitetsteori er et teoretisk rammeverk som løfter fram slike overveielser. Hovedpoenget her er at kunnskap skapes og læring foregår innenfor et aktivitetssystem. Skole, barnehage, lærerutdanning etc. er eksempler på slike aktivitetssystemer. De som deltar i et aktivitetssystem, utvikler kunnskap sammen, forhandler fram måter denne kunnskapen skal forstås på, og finner fram til ordforråd, symbolbruk, sjangerkunnskap og kommunikasjonsrutiner som er rådende innenfor aktivitetssystemet (Afdal, 2007, 2010; Engeström \& Rückriem, 2005; Lied, 2008, 2012). Erna Zonne, som har arbeidet med lærere som medforskere, skriver at lærere lettere forstår forskningsfunn knyttet til egen yrkeshverdag når det er kollegers refleksjoner de møter, eller når det er kolleger som presenterer funnene, fordi de da møter stoffet gjennom et språk som preger hverdagen deres (Zonne, 2007). Lied har framhevet det samme når det gjelder lærerstudenter: Lærestoff som er utviklet innenfor aktivitetssystemet lærerutdanning/ studentfellesskap setter raskt i gang forhandlinger og refleksjoner blant lærerstudenter rundt hvordan god undervisning skal være (Lied, 2012). Det vi her har framhevet, sannsynliggiør at elever i norsk grunnskole lettere vil kunne forstå innholdet i verdiene i skolens formålsparagraf når de får disse verdiene presentert i et språk og ved hjelp av symboler som preger den livsverden de er en del av, og forhandlingene som foregår der. 
Minnematerialet synes også å vise at det å sette ord og bilde på det grusomme, opplevdes både som en anerkjent og en nyttig ting å gjøre. Ytringsformen ga barn og unge mulighet til å kondolere og vise kjærlighet til og samhold med de som hadde mistet noen, og sende trøsteord til de som var skadet. Samtidig ga formen mulighet til à gi uttrykk både for sinne, fortvilelse og frykt. Slik delte de sine reaksjoner med andre. De ventet neppe konkrete svar på det de tegnet og skrev. Men kanskje kan bruken av minnematerialet på skolen likevel være med på å inspirere nye skrivere og tegnere til å ytre seg og delta i dialogen med verdiene som kommer til uttrykk her. Reaksjonene på terroren kommer her til uttrykk i et bildeog verbalspråk som skoleelever kan tåle fordi de er framstilt ved hjelp av språk og symboler som norske barn og unge er vel kjent med. Vi mener derfor at dette materialet kan være en god hjelp for lærere når temaet verdier står på timeplanen.

Barns og unges ytringer om 22. juli illustrerer både hvordan barn og unge var advokater for sentrale verdier i det norske samfunnet, verdier som også skolens formålsparagraf løfter fram, men også hvordan noen verdier ble satt under press (Lied og Stubø 2016). I det følgende vil vi gi eksempler på hvordan en kan arbeide med verdier på mellom- og ungdomstrinnet med tekster og bilder fra minnematerialet som læremiddel, hovedsakelig ved hjelp av Gunther Kress og Theo van Leeuwens grammatikk for vestlig design. Verdier i minnematerialet som er beslektet med de vi finner i formålsparagrafen, og som denne paragrafen løfter fram som sentrale, er i fokus.

\section{Kress og VAN LEEUWENS gramma- TIKK FOR VESTLIG VISUELL DESIGN4}

Kress og van Leeuwen studerer hvordan visuelle ytringer - som verbale tekster og tegninger - formidler mening (Kress \& Van Leeuwen, 2006). De understreker at den grammatikken de presenterer, er en grammatikk for som er typisk for ytringer i vestlig kultur. Når en ytrer seg, sier de, vil en nemlig alltid være i dialog med de uttrykksformer som er vanlige i det samfunnet en er en del av og kommuniserer inn i. Det er imidlertid viktig å understreke at dette ikke behøver bety at den som ytrer seg, alltid følger grammatikken i detalj. Både når en snakker og når en ytrer seg visuelt, vil en kunne komme til å bryte grammatikkens strenge regler.

I følge Kress og van Leeuwen må en lese fra toppen og nedover og fra venstre mot høyre når en møter en visuell ytring. De beskriver dermed en leseretning som går fra topp til bunn og fra venstre til høyre, og følger med det den leseretningen som er i bruk innenfor vestlig skriftkultur. I følge deres grammatikk inneholder den øverste delen av en komposisjon «the Ideal», ofte det vi ser som komposisjonens mest fremtredende informasjon eller dens viktigste tema. Den nederste delen, «the Real», presenterer mer detaljert og praktisk informasjon. Disse to delene utdyper hverandre, men den $\emptyset$ verste delen spiller alltid den ledende rollen. Den venstre siden av en komposisjon inneholder «the Given», det som det forventes at leseren allerede skal kjenne til som en del av kulturen, mens høyre side, «the New», inneholder det nye eller det som ikke er kjent eller akseptert som selvsagt, altså komposisjonens budskap.

4 Se fotnote 2. 
Kress og van Leeuwen peker også på at piler, linjer, blikk, snakkebobler osv. kan peke på viktige ting som skjer i en komposisjon. De fungerer altså som pekere. Størrelse, plassering, detaljer, farge og symboler framhever hva som framstår som viktig i bildet, og kan si noe om hva de ulike delene av komposisjonen betyr eller er innenfor en vestlig kultur.

Vårt utgangspunkt er altså at budskapet i tekstene og tegningene fra barn og unge etter 22.juli kommer fram bl.a. gjennom ytringenes design, f.eks. gjennom å framheve hva som er ytringens mest framtredende informasjon, hvilke detaljer som er med på å understreke denne informasjonen, hva som regnes som kjent, hva som er nytt og ukjent, viktige ting som skjer, og hva som står fram som viktig. Derfor kan arbeid med dette designet som arbeidsredskap hjelpe til med å løfte fram de verdiene som barn og unge presenterte som sentrale da de tegnet og skrev. Hvordan vi i skolen rent praktisk kan sette søkelyset på disse verdiene gjennom å arbeide med barns og unges ytringer, er tema for de neste avsnittene. Vi starter med mellomtrinnet og går deretter over til ungdomstrinnet. For begge trinnene bruker vi grammatikk for vestlig, visuell design som arbeidsverktøy i møte med minnematerialet.

\section{Arbeid med Verdier i minne-} MATERIALET: MELlomtrinnet

På mellomtrinnet skal elevene nærme seg et lærestoff gjennom bl.a. å samtale om det. Læreplanen i KRLE sier at elevene skal kunne gi uttrykk for og samtale om tanker de har om livet, sorg, godt og ondt, respekt og toleranse, at de skal kjenne til bruk av estetiske uttrykk, og at de skal kunne gi respons på andres tanker
(Kunnskapsdepartement, 2015). Dette vil prege det vi vil framheve i det følgende.

\section{Arbeid med verdiene liv, nestekjærlighet og solidaritet}

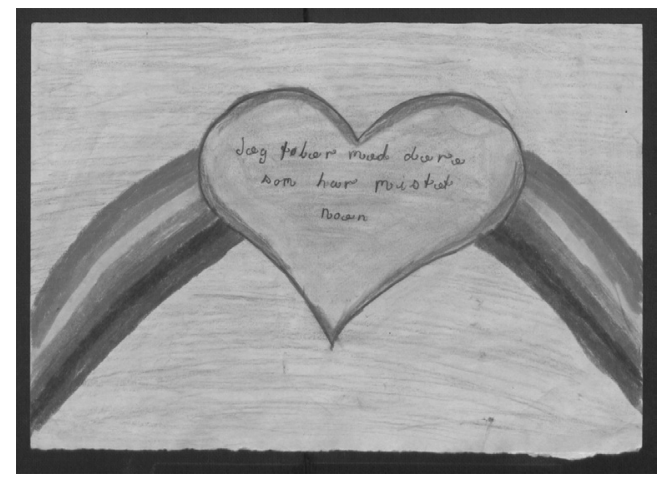

Fig. 1 For å se bildene i farger og større, se: http://www. iko.no/forlaget/metode-og-fag/prismet-nr-03-16

Fig. 1 er en ytring som løfter fram alle de tre verdiene liv, nestekjærlighet og solidaritet. Med utgangspunkt i Kress og van Leeuwens tenking er det naturlig å starte utforskningen av denne ytringen sammen med elevene og spørre: «Hva er det viktigste her? Hva er plassert i sentrum?» Det er ikke vanskelig å svare på dette. Hjertet er plassert midt på arket, og det er avgrenset med en kraftig, rød strek som er med på å framheve figuren. Regnbuen fungerer ved første øyekast som bakgrunn, men den er plassert slik at regnbuestrålene peker direkte mot hjertet. De fungerer altså som pekere, og er med på å rette oppmerksomheten vår mot det som er viktig i bildet, nemlig hjertet.

Fordi hjertet og regnbuen er kjente symboler i vestlig kultur, er det naturlig å spørre: «Hva betyr hjertet og regnbuen i denne ytringen?» I vestlig kultur knyttes hjertesymbolet vanligvis til verdien kjœrlighet. Men det er mer å si om hjertet i denne ytringen. For dersom vi leser verbalteksten 
som er plassert midt inne i hjertet, ser vi at den er med på å kvalifisere den kjærligheten som hjertet representerer: «Jeg føler med dere som har mistet noen», sier teksten. Det er altså en kjærlighet som har medmennesket i sentrum, som er avbildet her. Nestekjœrlighet er formålsparagrafens betegnelse på denne verdien.

De kraftige fargene regnbuen har fătt, er med på å gi også den en viktig rolle i bildet. Regnbuen er tradisjonelt et symbol for verdien enhet i mangfold eller samhold mellom enkeltindivider eller grupper på tvers av skillelinjer knyttet til bl.a. etnisitet, kjønn, språk og religion. Formålsparagrafens ord for dette er solidaritet. Regnbuen som samholds- og solidaritetssymbol er altså her med på å gi bakgrunn for, peke mot og understreke nestekjærligheten som hjertet representerer: Det var ikke bare etniske nordmenn som mistet livet på Utøya. Også unge med innvandrerbakgrunn ble drept. Både foreldre med etnisk norsk bakgrunn og med innvandrerbakgrunn sitter derfor sørgende igjen etter å ha mistet noen i terroren. Nestekjærligheten i denne ytringen inkluderer altså både enhet i mangfold og solidaritet på tvers av etniske skillelinjer.

Sammenkoblingen av verdiene (neste-) kjærlighet og samhold er noe vi ofte finner i barns og unges ytringer etter 22. juli 2011. Det ser ut til at både terrorhendelsen og reaksjonene i samfunnet etter denne, bevisstgjorde mange på viktigheten av nettopp disse verdiene: Kjœrlighet ble svaret på hatet Breivik demonstrerte. Samhold og solidaritet ble veien ut av fortvilelsen som ble skapt av sjokket og angsten for at noe slikt skulle komme til å skje igjen.

\section{Arbeid med verdier satt under press}

Barn og unge framhever livet som grunnleggende verdi i sine ytringer etter 22. juli, samtidig som de også framhever at denne verdien var den mest utsatte under terroren.5 Verdier som - ifølge barns og unges ytringer - ble satt under press under og i etterkant av terroren, er tema for dette avsnittet.

Livet som en verdi og som en menneskerett framstilles som truet i mange av tekstene og tegningene. Sorg og fortvilelse over at så mange unge ble fratatt livet, kommer klart til uttrykk. Dette ser vi blant annet av fig. 2, som løfter fram sorg over liv som har gått tapt:

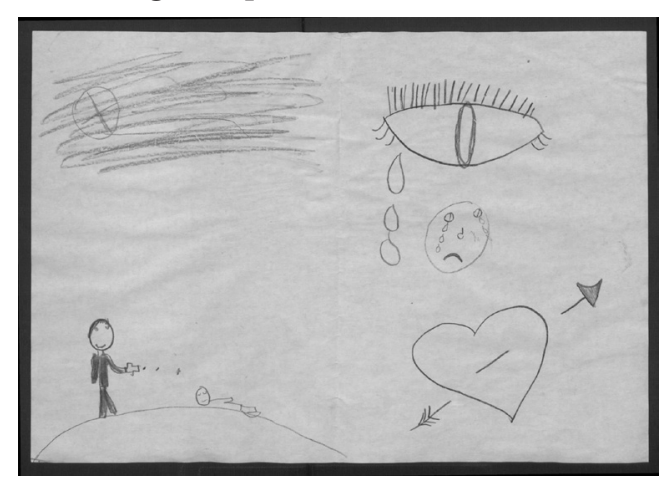

Fig. 2

Leser vi denne ytringen fra venstre mot høyre i tråd med vanlig vestlig leseretning, ser vi en mann med våpen i hånd som skyter en som ligger nede. Mannen smiler. Den som blir skutt, har lukkede øyne. Han er død. Ifølge Kress og van Leeuwens grammatikk for vestlig design, finner vi det gitte eller det som det forventes at alle skal kjenne til, på venstre side $\mathrm{i}$ en komposisjon. Alle vet at Breivik skjøt og drepte unge mennesker på Utøya. Mannen som skyter,

5 Livet fremstilles ofte som en grunnleggende verdi av forskere som arbeider med verdier og etikk (Barbosa da Silva, 2006; Bøckman, 1971; Heiene \& Thorbjørnsen, 2001; Hummelvoll, 2014; Vetlesen, 2014). 
er altså Breivik. Den høyre siden inneholder det nye eller komposisjonens budskap. Følger vi vanlig vestlig leseretning, starter vi øverst på siden, og leser nedover. Da ser vi først et stort øye som gråter, og under det et ansikt som er betydelig mindre enn øyet. Det gråter også. Nederst ser vi et skadet hjerte: Det går en pil gjennom det. Pilens endestykke peker mot haugen der offeret ligger nede. Kulene fra våpenet har også retning mot ham/henne.

Et stort øye brukes ofte i vestlig tradisjon som et symbol på Guds øye. Det er større enn menneskers øyne, og kan leses som Guds øye. Ansiktet under leses da som et menneskeansikt. Hjertet symboliserer vanligvis kjærlighet. Leser vi denne ytringen med en slik forståelse av symbolene, sier denne ytringen at Gud grăter, mennesket gråter og kjærligheten er skadet på grunn av det Breivik gjorde. Pilen og kulene fungerer som pekere og framhever en av bildets viktige aktører, nemlig den døde, samtidig som de retter oppmerksomheten mot hva som skjer i bildet: Breivik tok menneskers liv. Livet er verdifullt. Ikke noe menneske har rett til å ta livet fra et annet. Derfor sørger både Gud og mennesker over det onde som har skjedd.

På mellomtrinnet kan elevene bli utfordret til å lese denne ytringen ved hjelp av vestlig visuell grammatikk. Spørsmål en kan starte lesingen med, kan f.eks. være: «Hva tror du/dere at tegneren synes om det Breivik gjorde? Hva er det i tegningen som viser det?» Etter en påfølgende samtale der verdien liv står i fokus, kan en arbeidsoppgave f.eks. være: «Skriv og/eller tegn hva du/dere synes om det Breivik gjorde.» Dette er en arbeidsoppgave som kan være sentral når grunnleggende verdier i både kristen og humanistisk arv og tradisjon, i ulike religioner og livssyn og i menneskerettighetene (jfr. Formålsparagrafen) står på timeplanen.

Det er ikke bare livet som verdi barns og unges ytringer peker på at er satt under press 22. juli. Noen av ytringene løfter også fram menneskeverdet som en verdi som er truet (Lied og Stub $\emptyset$ 2016). Her vil vi trekke fram en ytring der denne verdien står i fokus og som kan være en god dialogpartner for elever på mellomtrinnet. Den handler om press mot minoriteters menneskeverd.

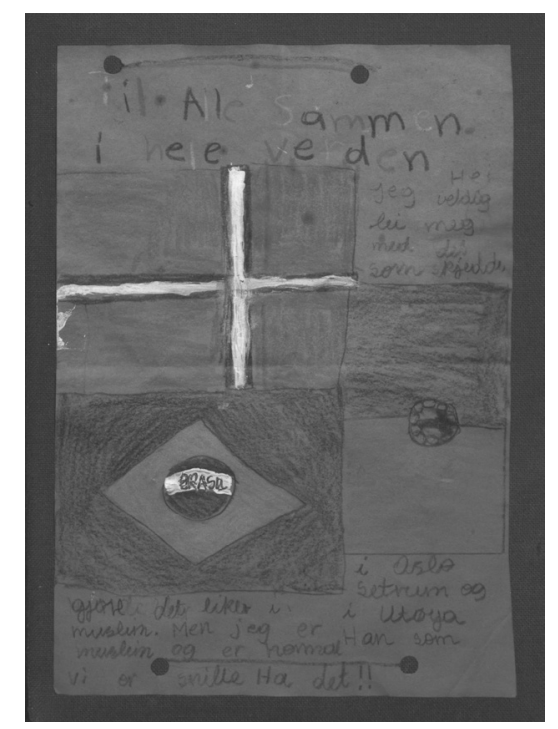

Fig. 3

Leser vi ovenfra og nedover, finner vi følgende hilsen fra et muslimsk barn i denne ytringen: «Til alle sammen i hele verden. Hei Jeg veldig lei meg med det som skjedde i Oslo sentrum og i Utøya. Han som gjore det liker ikke muslim. Men jeg er muslim og er normal Vi er snille Ha det!! » Tre flagg er tegnet inn i ytringen: På venstre side finner vi det norske flagget. Dette er det som står fram som det tydeligste. Like under er en utgave av det brasilianske flagget tegnet inn. På høyre side finer vi (muligens) det 
portugisiske. Representerer disse flaggene «hele verden»?

Siden vi finner en komposisjons sentrale tema øverst, er det viktig å merke seg at her finner vi en henvendelse til alle i hele verden. Spørsmålet som da presser seg fram, er: Hva er det som er så viktig for denne gutten å få sagt at han må henvende seg til alle i hele verden med budskapet? Går vi videre nedover i ytringen, til det som gir mer detaljert informasjon, ser vi at gutten er muslim og at han har forstått at terroristen ikke likte muslimer. Vi ser også at han er lei seg for det som skjedde 22. juli, slik de fleste andre i Norge er. Dessuten er han normal og snill, også noe de fleste andre i Norge er. Og det norske flagget står fram som det viktigste av ytringens tre flagg. En kan lese dette som at gutten presenterer seg både som muslim og typisk norsk.

Formålsparagrafens respekt for menneskeverdet kan være tema når en arbeider med denne ytringen på mellomtrinnet. For å aktivere elevenes evne til å reflektere og se en sak fra ulike sider, kan en f.eks. i felles klasse undre seg over hva mon den som har laget denne tegningen og teksten kan ha opplevd som gjør at han må si til alle i hele verden at han, som muslim, er normal og at muslimer er snille. Er han blitt mobbet fordi han er muslim? Har han opplevd negative følger av at «alle» en stund trodde at det var muslimske ekstremister som sto bak terroren? Har han, som et barn, opplevd ureflekterte generaliseringer og blitt satt i bås med terrorister? Hva har denne ytringen med respekt for menneskeverdet å gjøre? Er vi her i dialog med en ytring som sier noe om krenking av denne sentrale verdien?

$\emptyset$ nsker en å arbeide videre med dette temaet etter en slik felles refleksjonsrunde, kan en bl.a. gi elevene følgende prosessbaserte oppgave: (a) skrive ned sine egne tanker i møte med fig. 3, (b) dele teksten sin med sidemannen, (c) presentere teksten i plenum. En slik prosess vil gi elevene anledning til å reflektere over dette temaet en stund alene. De vil også få trening i å sette ord på tankene sine og dele dem med én person. Disse to trinnene kan være en god forberedelse til å delta i en meningsutveksling i plenum. Det er selvsagt mulig å stoppe etter (a) eller (b) dersom en som lærer finner at det er det mest tjenlige for elevene i møte med et sterkt materiale.

\section{Arbeid med verdier i minne- MATERIALET: UNGDOMSTRINNET}

\section{Arbeid med verdiene liv, nestekjærlighet og solidaritet}

Elever på ungdomstrinnet har kapasitet til å møte større filosofiske utfordringer enn yngre elever. Dette kommer også til uttrykk bl.a. i kompetansemålene for fagene, der arbeidsmåter som framheves, er drøfting av ulike syn med respekt, refleksjon over tema knyttet til menneskeverd, menneskerettigheter og mellommenneskelige relasjoner, begrunnelse av meninger, og drøfting av utfordringer i flerkulturelle samfunn. Flere av ytringene fra minnematerialet kan det være både inspirerende og utfordrende for ungdomsskoleelever å møte når arbeid med denne type kompetansemål står på agendaen. I det følgende vil vi gi eksempler på hvordan en på ungdomstrinnet kan arbeide med en ytring der verdiene liv, nestekjærlighet og solidaritet er sentrale.

Vi vil imidlertid understreke at selv om vi her gir eksempler som er rettet mot ungdomstrinnet, kan de samme ytringene også tilpasses mellomtrinnet og brukes der. 
Til ettertanke

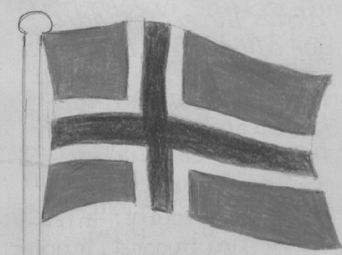

Du maitle senke

vart flagg med

makt. Vi reiste

clet igjen med

kjorlighet

Fig. 4

Vi starter også her lesingen av fig. 4 øverst. «Til ettertanke» sier overskriften. Et rosa hjerte er plassert umiddelbart etter denne og fungerer som et punktum eller utropstegn. Overskriften får oss umiddelbart til å spørre: «Hva er det vi skal tenke over?» Leser vi videre nedover, får vi den informasjonen vi trenger. Først møter vi flagget. Dets størrelse, fargeintensitet og sentrale plassering viser at her møter vi noe av det som er viktig i komposisjonen. Flaggets sentrale betydning understrekes videre $\mathrm{i}$ verbalteksten som følger like under: «Du måtte senke vårt flagg med makt. Vi reiste det igjen med kjærlighet», står det.

Det siste ordet i verbalteksten - kjærlighet - knytter an til hjertet i overskriften. Kjærlighet blir dermed det temaet som knytter ytringen sammen til en helhet. Men kjærlighet er ikke det eneste hovedtemaet i ytringen. Flaggets sentrale plassering antyder at også det er bærer av en av ytringens sentrale idéer. Flagget står tradisjonelt for samhold, fellesskap og solidari- tet i Norge. ${ }^{6}$ Ytringens hovedbudskap - det som er til ettertanke - er altså knyttet til verdiene kjærlighet og samhold, fellesskap og solidaritet.

Verbalteksten starter med å henvende seg til Breivik. Han settes i kontrast til oss: Han senket flagget vårt - som representerer fellesskap og samhold - med makt, men vi reiste det igjen med kjærlighet. Han sto for ødeleggelsen, vi for gjenopprettelsen: Han ville ødelegge fellesskapet og samholdet, men vi sto sammen i kjærlighetens protest mot det onde han gjorde. Han gjorde ondt, vi gjorde godt. Han er ikke oss.

Det er mange tema som kan settes på sakskartet når en arbeider med denne ytringen. Solidaritet og fellesskap er brennhete tema nå når dette skrives og Europa utfordres av flyktninger som søker beskyttelse. Refleksjoner - både muntlig to og to og/eller i samlet klasse, og skriftlig en og en eller to og to - kan lede elevene i dialog både med egne og medelevers tanker om dette. Slik kan de få mulighet til både å utdype og justere egne verdier og holdninger. Spørsmål som kan reises, kan f.eks. være: Hvorfor er solidaritet og fellesskap viktig i et samfunn? Hva har kjærlighet med disse to verdiene å gjøre? Det var lett å vise samhold og kjærlighet i dagene etter 22. juli 2011 - hvordan kan vi vise samhold og kjærlighet i dag?

Det er et annet spørsmål som også brenner her, og som både er knyttet opp mot fellesskap og solidaritet som verdikompleks og mot en annen, men beslektet, verdi, nemlig respekt for menneskeverdet. For når Breivik settes opp mot oss slik det gjøres her, kan man spørre: Hvem er inklu-

\footnotetext{
6 Forståelsen av det norske flagg som et samholds-, fellesskaps- og solidaritetssymbol kan en finne mer om i Lied og Undseth Bakkes artikkel «Canon and archive in messages from Oslo Cathedral Square in the aftermath of July 22nd 2011» (Lied \& Undseth Bakke, 2013).
} 
dert i det norske «vi»»? Hvem er utenfor og hvem er innenfor? Er det virkelig slik at $v i$ er bare gode og han er bare ond, og så kan vi slå oss til ro med det? Må denne kontrasten nyanseres noe? Dette er spørsmål som også den neste ytringen - fig. 5 - aktualiserer, og som det kan være bevissthetsutvidende for ungdomsskoleelever å arbeide med.

\section{Arbeid med verdier som ble satt under press}
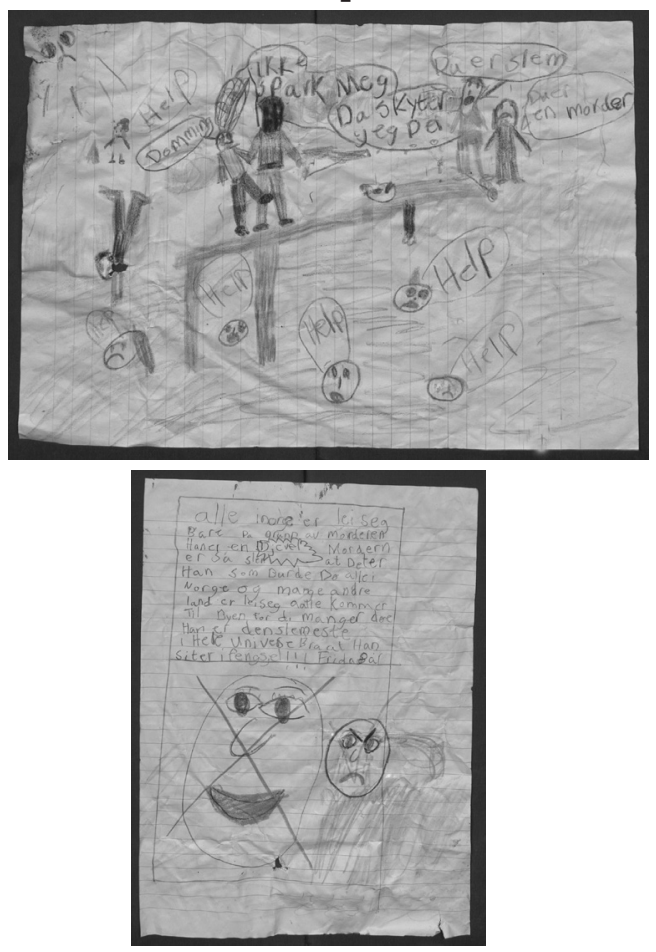

Fig. 5

Dette er en multimodal ytring som har to sider. Den første viser det som skjedde på Utøya, altså det som i følge Kress og van Leeuwen forventes kjent. Breivik er tegnet med en svart hette over hodet. Han sier til den som står ved siden av ham, sparker ham og kaller ham «Domming», at han ikke skal sparke: «Ikke spark meg.
Da skyter jeg dei». Denne trusselen synes reell, for det ligger en person med langt lyst hår og en rød flekk i pannen, utstrakt på brygga. Hun er trolig skutt. To personer står på graset ved siden av kaien og ser på det som skjer. «Du er slem,» sier den ene. «Du er en morder,» sier den andre. Flere mennesker svømmer omkring i vannet og roper om hjelp. Hele scenen er så grufull at selv sola ser forskrekket ut.

Side to inneholder det nye eller ytringens budskap. Det er nært knyttet til det som er skildret på foregående side: «alle i norge er lei seg bare på grunn av morderen Han er en DJEVEL Morderen er så slem at det er han som burde dø. Alle i Norge og mange andre land er lei seg og alle kommer til byen fordi mange er døe Han er den slemeste i hele universet Bra han sitter i fengsel!!!!’ Det er verdt å merke seg at det er det grufulle som skildres på første side, som er utgangspunktet for denne sterke teksten.

Fig. 5 som helhet viser et hatpreget sinne mot Breivik og hans handlinger som var lite i fokus i dagene etter terroren 22. juli. Tegningen gir Breivik en svart hette som dekker ansiktet. Slik står han fram som ansiktsløs, noe som er med på å redusere det menneskelige ved ham. Teksten gjør ham til en morder og en djevel det ikke finnes maken til i hele universet, noe som gjør ham ennå mer umenneskelig. Denne jenta $\emptyset$ nsker at den umenneskelige, ansiktsløse djevelen Breivik som tok forsvarsløse unge menneskers liv, var død. En djevel som dreper, bør jo selv bli drept! Jentas dialog med terroristens handlinger kan, med andre ord, ses som et forsvar for verdien liv, en verdi hun opplever som truet av Breiviks drapshandlinger på Utøya.

Det kan være tankevekkende for ung- 
domsskoleelever å arbeide med denne ytringen, fordi den kan tolkes som et utsagn som setter to grunnleggende verdier opp mot hverandre, nemlig retten til liv og respekten for menneskeverdet (se Formålsparagrafen). Dehumaniseringen av Breivik og alderen på de menneskene han berøvet livet, gjør det lett å være enig med den rasende 8-årige jenta. I denne sammenheng kan det imidlertid også være interessant å trekke inn det norske rettssystemets behandling av terroristen. I dette systemet er ikke dødsstraff et alternativ. Derfor var dette heller ikke diskutert i forbindelse med rettssaken mot Breivik. Rettsapparatet la derimot stor vekt på å gi ham en juridisk korrekt behandling, noe som bl.a. inkluderte det å behandle ham som et menneske med menneskeverdet $\mathrm{i}$ behold: Han fikk stille både velkledd og med talerett i rettssalen, og både aktor, forsvarere og dommere henvendte seg høflig til ham gjennom hele rettssaken. Behandlingen av Breivik i det norske rettssystemet vakte oppsikt i flere utenlandske media. Det kan være en idé her å diskutere hva som kan være grunnen til denne reaksjonen, med elevene. Det kan også være en idé å sammenligne andre lands og norsk behandling av mordere gjennom eksempelvis et filmklipp. Dette vil det være enkelt å finne på Youtube.

Spørsmål som kan være interessante å drøfte med elevene i møte med 8-åringens ytring, kan ha menneskeverdet i sentrum: Hva er «saken» her? Går det an å støtte jenta i raseriet mot Breivik? Hvorfor/hvorfor ikke? Kan kampen for verdien liv føre til at andre verdier - f.eks. respekt for menneskeverdet - kommer under press? Hva vinner og hva taper vi da? En kan være enig eller uenig i hvordan Breivik ble behandlet i det norske rettsapparatet. Poenget her vil være å framheve hvorfor han ble behandlet som han ble, og f.eks. forankre dette i menneskerettighetene. Det kan da være en fordel å ha arbeidet med menneskerettigheter og menneskeverd med klassen i forkant.

Dersom læreren kjenner klassen sin godt og vet at den har trening i å drøfte etiske dilemmaer, kan en også, med bakgrunn $i$ en grundig gjennomgang av lærebokas framstilling av FNs menneskerettighetserklæring, føre denne diskusjonen på et mer allment plan. En kan f.eks. se på hvordan menneskerettighetene framhever likhet for loven og tydelig tar avstand fra tortur. En kan også utfordre elevene med spørsmål som: Har en massemorder menneskeverd? Har han krav på en juridisk forsvarlig rettssak? Går det på ofrenes menneskeverd løs dersom morderen får en respektfull behandling? Hva vinner et land på å sette respekt for menneskeverdet i høysetet? Taper det noe? I tilfelle hva? Kommenter følgende uttalelse fra sosiale medier: «La oss putte han i et hull hvor vi kan drite og pisse på han».

Når en arbeider med verdier som er under press, kan fig. 3 være et alternativ også på ungdomstrinnet. Det kan være en fin utfordring for elevene å se denne ytringen i lys av to uttalelser, en fra Dagsavisen 25. juli og en fra Facebook. Begge uttalelsene ligger nær opp til det vi kan kalle hat og rasisme: «Nå ligger dere jævla tynt an. Jeg hater dere, jævla negre» og «Nei folkens, no tar vi med hagla og melde oss på teatime! »>7 Dette kan en gjøre for å skildre noe av det negativt ladede bakteppet som kom til syne etter terrorhandlingene, og for

\footnotetext{
7 Tea Time refererer til et program fra Anti-rasistisk senter som inviterer muslimer og ikke-muslimer til å drikke te sammen for å bli bedre kjent.
} 
å illustrere verdier som ble satt under press. I en slik sammenheng kan en presisere at disse hatutsagnene representerer et ytterpunkt sett i lys av alle kjærlighets- og samholdserklæringene som kom i tiden etter 22. juli. Det kan imidlertid være lærerikt for elevene at slike ytringer ikke bagatelliseres. Det forekom kommentarer og handlinger av rasistisk karakter rettet mot muslimer umiddelbart etter terroren, også etter at det ble kjent at terroristen var etnisk norsk (Murtnes, 2011; Vikås, 2011; Zondag, 2011), noe fig. 3 kan leses som et svar på.

\section{Arbeid med verdien tilgivelse}

Det kan være lærerikt for ungdomsskoleelever også å møte en motsats til fig. 5 og den 8 -årige jentas rasende ytring. Fig. 6 kan åpne for et arbeid der verdiene nestekjærlighet og tilgivelse står i fokus, verdier som skolens formålsparagraf framhever.

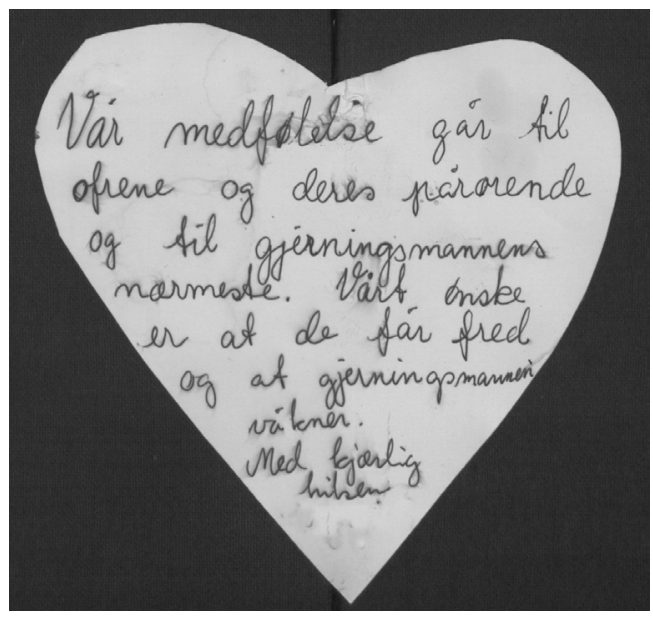

Fig. 6

Her ser vi et hjerteformet ark som omslutter og gir ramme for en verbaltekst. Hjertet får dermed form av en peker som viser hva som er viktig i komposisjonen. Siden hjertet også er et symbol på kjærlighet, kan verbalteksten leses som et kjærlighets- utsagn: «Vår medfølelse går til ofrene og deres pårørende og til gjerningsmannens nærmeste. Vårt $\emptyset$ nske er at de får fred og at gjerningsmannen våkner. Med kjærlig hilsen X og X». De som har skrevet denne teksten, synes å ha vært i bevisst dialog med verdiene nestekjærlighet og tilgivelse når de her understreker at ikke bare ofrene og ofrenes pårørende, men også Breiviks nærmeste trenger medfølelse etter det som har hendt. Nestekjerligheten kommer til uttrykk gjennom hjertet og medfølelsen som uttrykkes eksplisitt gjennom teksten. Tilgivelsen kommer til uttrykk gjennom at terroristen («gjerningsmannen») og hans nærmeste er skrevet inn i det hvite hjertet.

I arbeid med denne ytringen kan en f.eks. spørre elevene om hvilken betydning de mener formen på arket har for forståelsen av denne ytringen, og om å begrunne svaret sitt. De kan f.eks. bes om å ta stilling til følgende utsagn: «Skriverne har altså klart å inkludere i sin omtanke ikke bare de det var lett å elske, men også de det var lett å klandre i tiden etter 22. juli.» Elevenes svar kan så være utgangspunkt for arbeid med begrepet tilgivelse. I lys av denne teksten kan tilgivelse forstås som vilje til å gi slipp på hat og bitterhet - ikke først og fremst fordi gjerningsmannen fortjener det, men fordi det kan hjelpe oss, som medmennesker, til å bli fri for ødeleggende følelser og fă fred. Et annet alternativ kan være å be elevene om å lete etter verdier de mener er sentrale i ytringen. Dette kan de gjøre enten alene, sammen to og to eller i gruppe, muntlig eller skriftlig. De kan i tillegg bes om å utdype hva de legger i disse verdiene.

Oppgaven som elevene får i møte med denne ytringen, kan også ha form av et tverrfaglig opplegg mellom fagene norsk, KRLE og samfunnsfag. Utgangspunkt kan 
da f.eks. være formålsparagrafen som knytter verdiene nestekjærlighet og tilgivelse til kristen og humanistisk arv og tradisjon, til andre religioner og livssyn og til menneskerettighetene. Elevene kan få i oppdrag å finne referanser fra ulike religioner og livssyn som framhever nestekjærlighet og tilgivelse, og lete fram fortellinger, dikt, salmer o.a. fra de ulike tradisjonene som markerer disse verdiene. De kan også gis som oppgave å fortelle fra litteratur eller reportasjer de har lest, bilder de har sett, mennesker de har hørt om eller møtt etc., som representerer disse verdiene.

\section{UTPRØVING AV MINNEMATERIALET I SKOLEN}

Kveset har i forbindelse med arbeidet med minnematerialet prøvd ut ulike opplegg i skolen, bl.a. et opplegg i en klasse på 9 . trinn. Det kan være med på å illustrere hvordan barn og unge voksne selv setter på agendaen det de er klare for å møte, i dette tilfellet temaet brutal død. Både elever og foresatte fikk orientering om at dette var et forskningsprosjekt, at deltakelse var frivillig, og at elevene kunne trekke seg fra prosjektet når de måtte ønske det. Elevene fikk møte to ytringer fra minnematerialet, henholdsvis fig. 7 og fig. 8, uten noen annen forklaring på hvor de var hentet fra.

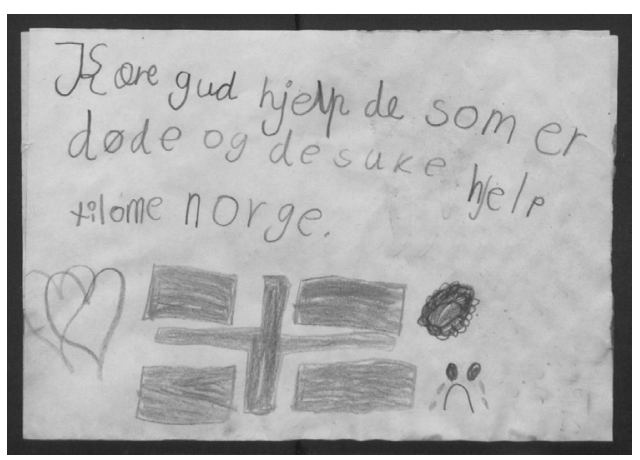

Fig. 7
De ble kun oppfordret til å skrive ned hvilke tanker, ideer, spørsmål eller påstander de gjorde seg i møtet med disse to multimodale ytringene.

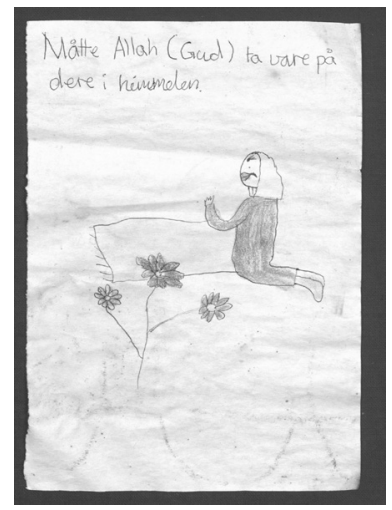

Fig. 8

Fig. 7 har en verbaltekst $\emptyset$ verst som sier: «Kjære gud hjelp de som er døde og de suke hjelp tilome norge. Hilsen $\mathrm{xx}$. » Under denne verbalteksten er det tegnet et hjerte, et flagg og et gråtende ansikt. Øverst på fig. 8 er en verbaltekst som sier: «Måtte Allah (Gud) ta vare på dere i himmelen.» Under teksten ser vi ei jente på kne på et teppe, og tre blomster.

Noen av påstandene elevene kom med i møte med disse ytringene, og som vi samlet på tavla, var: «skjedd noe i hjemlandet», «Trist», « Hører Gud oss i Norge?», «Mista noen», «Brutal d $\emptyset \mathrm{d} \gg$, «Barn engasjerer seg gjennom tegning $\gg$, «Hva skjer når vi dør?» Vi ønsket at elevene selv skulle få avgjøre hvilken påstand klassen skulle arbeide videre med. Dette avgjorde de gjennom avstemning. Brutal død fikk flertall. Elevene snakket sammen i grupper om dette temaet og skrev deretter ned tankene sine. Selv om det ikke kom frem i tekstene de skrev, fremkom det under denne arbeids $\emptyset \mathrm{kta}$ en viss oss- og dem-mentalitet i klassen. Dette kom spesielt til uttrykk 
i en av gruppene hvor terrorangrepet mot Charlie Hebdo ble brakt på banen. Elevene argumenterte for at det var riktig av oss å trykke karikaturer av deres profet, da det var de som hadde angrepet oss. Her kan en forstå elevenes tanker både som et uttrykk for mangel på toleranse og respekt, og som mangel på kunnskap. Her kunne vi - for å følge opp denne problemstillingen - ha tatt utgangspunkt i verdien toleranse som her kan ha vært under press, og reflektert over den sammen med elevene. Det hadde også vært mulig à ta opp problemkomplekset åndsfrihet, ytringsfrihet, toleranse og respekt i denne sammenhengen. Det kunne gitt klassen mulighet til å drøfte forholdet mellom det å gi uttrykk for det en står for og å forholde seg til andres standpunkter med ydmykhet og respekt.

Elevene valgte selv brutal $d ø d$ som tema for samtale, noe som illustrerer at de var både klare for og i stand til å møte dette temaet. Det kan likevel være interessant å påpeke at to elever trakk seg fra videre deltakelse f $\emptyset \mathrm{r}$ vi var ferdige med arbeidet, men de ønsket likevel å gi oss tekstene de hadde skrevet. Det kan være ulike grunner til at de valgte en slik løsning. De visste at deltakelse var frivillig og at de hadde mulighet til å trekke seg når som helst om de ønsket det. Det kan være at elevene $\emptyset$ nsket å teste ut denne muligheten. Men i arbeid med 22. juli i skolen må en også være bevisst at tematikken kan være ubehagelig for enkelte og vekke sterke følelser. Norge er et lite land. Det var mange som ble rammet av terroren. Det er derfor stor sannsynlighet for at noen i klasserommet kan bli berørt på en eller annen måte. Når det er sagt, er ikke det en grunn til å unnvike tematikken - heller tvert imot. Barn og unge vil, som deltakere i det norske samfunnet, bli konfrontert med denne hendelsen på ulike måter. Med klasserommet som ramme vil de kunne delta i refleksjoner rundt temaet - med læreren som voksen samtaleleder og innenfor sosiale og kommunikative rammer de er kjent med.

Erfaringer etter de utprøvingene Kveset har hatt på ungdomstrinnet, er at minnematerialet er et godt læremiddel å bruke $\mathrm{i}$ skolen. Samtidig som materialet kan hjelpe elevene til å bli mer bevisst de verdier som norsk skole ønsker å formidle, kan det også hjelpe lærere til å tematisere de samme verdiene. Det kan også være et utgangspunkt for å samtale om terroristens tankegods. Ytringer som kan knyttes til dette, kommer stadig til uttrykk i sosiale mediers kommentarfelt, fra politikere og i enkelte nyhetsmedier. Kvesets utprøvinger har vist oss at 22. julimaterialet fortsatt er relevant for barn og unge, og nye terrorangrep $\mathrm{i}$ ulike deler av verden er ikke med på å gjøre materialet mindre aktuelt, heller det motsatte. Utfordringene som er knyttet til bruken av dette materialet er ikke større enn i møte med andre temaer i KRLE-faget og i samfunnsfag: Det fordrer lærere som er seg bevisst at norsk skole ikke er verdinøytral, og at det er skolens samlede oppgave å fremme formålsparagrafens verdier. Minnematerialet etter 22. juli aktualiserer og konkretiserer noen av disse verdiene, og kan derfor være et godt utgangspunkt for arbeid med skolens verdiplattform.

\section{LitTERATUR}

Riksarkivets lenke til den offentlige og fritt tilgjengelige delen av minnematerialet: http://arkivverket.no/URN:db_read/ $\mathrm{db} / 15749$ 
Aagedal, O., Botvar, P. K., \& Høeg, I. M. (2013). Den Offentlige sorgen: markeringer, ritualer og religion etter 22. juli. Oslo: Universitetsforl.

Afdal, G. (2007). Researching religious education as social practice. Halden: Høgskolen i $\emptyset$ stfold.

Afdal, G. (2010). Researching religious education as social practice (Vol. vol. 20). Münster: Waxmann.

Barbosa da Silva, A. e. a. (2006). Etikk og menneskesyn $i$ helsetjeneste og sosialt arbeid. Oslo: Gyldendal akademisk.

Bøckman, P. W. (1971). Liv, fellesskap, tjeneste: en kristen etikk (2. oppl. ed.). Oslo: Universitetsforl.

Dewilde, J., \& Igland, M.-A. (2015). "No problem, janem". Et transspråklig perspektiv på elevers skriving. In E. N. Selj \& A. Golden (Eds.), Skriving på norsk som andrespråk (pp. 96-111). Oslo: Cappelen Damm Akademisk.

Engeström, Y., \& Rückriem, G. (2005). Developmental work research expanding activity theory in practice. Berlin: Lehmanns Media.

Heiene, G., \& Thorbjørnsen, S. O. (2001). Fellesskap og ansvar : innføring i kristen etikk ([2. utg.]. ed.). Oslo: Universitetsforl.

Hummelvoll, J. K. (2014). Helt - ikke stykkevis og delt. Psykiatrisk sykepleie og psykisk helse (7th ed.). Oslo: Gyldendal Akademisk.

Kress, G., \& Van Leeuwen, T. (2006). Reading images : the grammar of visual design. London: Routledge.

Kunnskapsdepartement, D. k. (2015). Lœreplan for Kristendom, religion, livssyn og etikk.

Kunnskapsdepartementet. (2009). Opplæringslova. http://lovdata.no/all/nl19980717-061.html: http://lovdata.no/all/ nl-19980717-061.html. Retrieved from http://lovdata.no/all/nl-19980717-061. html.
Kunnskapsdepartementet, \& Utdanningsdirektoratet. (2006). Læreplanverket for Kunnskapsløftet (Midlertidig utg. juni 2006 ed.). Oslo: Utdanningsdirektoratet.

Lied, S. (2004). Elever og livstolkingspluralitet $i \mathrm{KRL}$-faget : mellomtrinnselever i møte med fortellinger fra ulike religioner og livssyn. Elektronisk ressurs. Elverum: Høgskolen i Hedmark.

Lied, S. (2008). Forskningsfellesskap med aktivitetsteoretisk profil. Prismet, 3/20o8, årgang 59, 171-182.

Lied, S. (2012). Studenter i forskning - ett svar på utfordringer fra det flerkulturelle og livstolkingsplurale klasserommet. Vallset: Oplandske Bokforlag.

Lied, S., \& Lödén, H. (2014). Minnematerialet etter 22.juli: En kilde til informasjon om det norske samfunnet. Arkivmagasinet, 29-32.

Lied, S., \& Undseth Bakke, S. (2013). Canon and archive in messages from Oslo Cathedral Square in the aftermath of July 22nd 2011. Nordidactica (1), 34-56.

Lippestad, G. (2013). Det vi kan stå for. Oslo: Aschehoug \& co.

Murtnes, S. (2011). Kadra: Muslimer ble jaget nedover gatene, http://www. vg.no/nyheter/innenriks/terrorangrepet -22-juli-politikk-og-samfunn/kadra -muslimer-ble-jaget-nedover-gatene/ a/10088913/. Retrieved from http:// www.vg.no/nyheter/innenriks/terrorangrepet-22-juli-politikk-og-samfunn/ kadra-muslimer-ble-jaget-nedovergatene/a/10088913/

Norli, S., \& Gausdal, O. (2013). 22. juli-arkivene i Riksarkivet. [arkiv]magasinet(1/13), 38-41.

Stoltenberg, J. (2011). Sjokkerende og feigt. Tale holdt 22. juli 2011. http://www. regjeringen.no/nb/dep/smk/aktuelt/ 
taler_og_artikler/statsministeren/statsminister_jens_stoltenberg/2011/sjokkerende-og-feigt.html?id=673127

Stormark, K. (2011). Da terroren rammet Norge: 189 minutter som rystet verden. Oslo: Kagge.

Stormark, K. (2012). Massemorderens private e-poster. Oslo: Spartacus.

Vetlesen, A. J. (2014). Studier i ondskap. Oslo: Universitetsforlaget.

Vikås, M., med flere. (2011). Oppfordret hijabkledde jenter om å holde seg innendørs, http://www.vg.no/nyheter/innenriks/ terrorangrepet-22-juli-politikk-ogsamfunn/oppfordret-hijabkledde-jenterom-aa-holde-seg-innendoers/a/10088956/. Retrieved from http://www.vg.no/nyheter/innenriks/terrorangrepet-22-juli-politikk-og-samfunn/ oppfordret-hijabkledde-jenter-om-aaholde-seg-innendoers/a/10088956/

Zondag, M. H. W. (2011). Muslimer ble hetset etter terroren, http://www.nrk.no/ norge/meldinger-om-muslim-hets-ioslo-1.7723535. Retrieved from http:// www.nrk.no/norge/meldinger-om-muslim-hets-i-oslo-1.7723535

Zonne, E. (2007). Working with Religious Education Teachers as Co-Researchers. In C. Bakker \& H.-G. Heimbrock (Eds.), Researching RE Teachers. RE Teachers as Researchers (pp. 71-81). Münster: Waxmann. 